\title{
O rozprawie doktorskiej Macieja Gałęzowskiego, obronionej w 1812 roku w Wilnie
}

\author{
About Maciej Galezowski's dissertation, defended \\ in 1812 in Vilnius
}

\author{
Anita Magowska ${ }^{1}$
}

Poznań

\begin{abstract}
Streszczenie: Artykuł omawia rozprawę doktorską Macieja Gałęzowskiego, która została obroniona w 1812 roku na Uniwersytecie Wileńskim. By odsłużyć stypendium rządu rosyjskiego, jej autor musiał po studiach pracować jako lekarz wojskowy. Promotorem dysertacji był Józef Frank, a tematem rozpoznawanie, różnicowanie i leczenie internistyczne oraz chirurgiczne hemoroidów. Rozprawa ukazuje zainteresowanie lekarzy semiotyką medyczną oraz przemiany chirurgii i medycyny na początku XIX wieku.

Abstract: This article presents a doctoral thesis written by Maciej Galezowski and defended in 1812 in Vilnius. During his studies, Galezowski received the Russian government scholarship, hence, he was obligated to serve as doctor in the Tsar military units. Galezowski write the dissertation under Joseph Frank. His thesis was on hemorrhoids, their diagnostics and medical and surgical treatment. The dissertation shows physicians' interest in medical semiotics and evolution of surgery and medicine at the beginning of the 19 th century.
\end{abstract}

Słowa kluczowe: semiotyka medyczna, gastroenterologia, hemoroidy, dysertacje lekarzy, XIX wiek, Wilno

Keywords: medical semiotics, gastroenterology, hemorrhoids, doctors' dissertations, 19th century, Vilnius

Każda z rozpraw doktorskich opublikowanych przez lekarzy w XVIII i XIX wieku zasługuje na baczna uwagę jako obraz przemian medycyny jako sztuki i nauki. Nie inaczej jest z dysertacją Macieja Gałęzowskiego zatytułowaną „Dissertatio inauguralis medici practica de haemorrhoidibus in genere et praecipue de cura haemorrhoidum coecarum” („Rozprawa inauguracyjna medyczno-praktyczna o guzach krwawniczych w ogólności, a szczególnie o leczeniu żylaków odbytu zamkniętych [ślepych]"), a obronioną w Wilnie w 1812 roku² $^{2}$. Maciej Gałęzowski pochodził z Litwy, a więc nie

\footnotetext{
1 ORCID 0000-0002-6046-3993. Katedra i Zakład Historii i Filozofii Nauk Medycznych Uniwersytetu Medycznego w Poznaniu.

2 M. Gałęzowski, Dissertatio inauguralis medico practica de haemorrhoidibus in genere, et praecipue de cura haemorrhoidum coecarum, Vilnae 1812, ss. 26.
} 
mógł być bliskim krewnym nieco od niego młodszego i urodzonego na Ukrainie Seweryna Gałęzowskiego (1801-1878), także absolwenta Cesarskiego Uniwersytetu Wileńskiego, a z czasem znanego lekarza nie tylko w ojczyźnie, ale i w Meksyku oraz Francji, animatora życia polskiej emigracji politycznej ${ }^{3}$.

O Macieju Gałęzowskim wiadomo znacznie mniej niż o Sewerynie. Pochodził z niezamożnej rodziny szlacheckiej. Studiował medycynę na Cesarskim Uniwersytecie Wileńskim korzystając ze stypendium rządu rosyjskiego oraz pomocy materialnej księdza prałata Katedry Wileńskiej Stanisława Lachnickiego, okresowo zarządzajacego również diecezją wileńską. Lachnicki umożliwił młodemu adeptowi medycyny druk rozprawy doktorskiej w drukarni diecezjalnej, a ten z wdzięczności za mecenat zadedykował duchownemu swoją dysertację. Po ukończeniu studiów Maciej Gałęzowski był zobligowany do odsłużenia stypendium w wojsku carskim. Został lekarzem batalionowym, a po zakończeniu służby praktykował jako lekarz w majątku Bienica położonym koło miejscowości Oszmiany w guberni wileńskiej. Niewykluczone, że majątek ten zakupił za zgromadzone podczas służby oszczędności, bo tak często postępowali polscy lekarze $\mathrm{w}$ zaborze rosyjskim ${ }^{4}$.

Z dzisiejszej perspektywy dysertacja M. Gałęzowskiego porusza problematykę gastroenterologii, jednak współcześni autorowi lekarze nie mieli podstaw, by przewidywać powstanie takiej specjalności. Jeszcze w 1835 roku John Forbes (1787-1861), absolwent studiów chirurgicznych i lekarskich w Edynburgu, popularyzator zastosowania stetoskopu na Wyspach Brytyjskich, a wkrótce założyciel „A Quarterly Journal of Practical Medicine" i lekarz królowej Wiktorii ${ }^{5}$ zaliczał publikacje poświęcone hemoroidom do semiotyki medycznej. ${ }^{6}$. Były interesujące, bo dotyczyły fenomenu choroby częściowo ukrytej we wnętrzu ciała i dlatego za życia pacjenta niepoznawalnej. Znajomość objawów i umiejętność ich różnicowania miały zatem duże znaczenie diagnostyczne, pozwalały wykazać się znajomością sztuki lekarskiej. Tak zapewne nauczał studentów medycyny Józef Frank (1771-1842), kierownik kliniki terapeutycznej Cesarskiego Uniwersytetu Wileńskiego. Bez oparcia o jego autorytet M. Gałęzowski nie dowodziłby, że lekarz jest w stanie rozpoznać hemoroidy, odróżnić je od innych chorób przewodu pokarmowego i stosując gradację terapii, od zmiany trybu życia do upustu krwi, wyleczyćc .

Hemoroidy były znane już starożytnym medykom. Ich najstarszy opis pochodzi z egipskich papirusów, a sporo uwagi poświęcił im Celsus. W średniowieczu do standardów praktyki chirurgicznej zaliczało się podwiązywanie i wycinanie guzków krwawniczych oraz leczenie ich poprzez upusty krwi. Proces odbierania chirurgom

S. Gałęzowski, Dissertatio inauguralis de Variola mitigata, Vilnae 1824.

4 S. Kośmiński, Stownik lekarzów polskich, Warszawa 1883, s. 133; P. Szarejko, Stownik lekarzy polskich XIX wieku, t. IV, Warszawa 2007, s. 155.

5 Agnew RAL (2005). John Forbes FRS (1787-1861). The James Lind Library, <www.jameslindlibrary. org>, dostęp: 24 luty 2019.

6 J. Forbes, A Manual of Select Medical Bibliography in which the books are arranged chronologically according to the subject, Londyn 1835, s. 98. Bibliografia była zadedykowana prof. Uniwersytetu w Edynburgu - Robertowi Jamesonowi.

7 M. Gałęzowski, Dissertatio inauguralis..., s. 18-23. 
wyłączności na leczenie hemoroidów został zapoczątkowany przez Holendra J. C. de Haëna, który w 1675 roku opublikował mowę "Quo quis rectius cognosut morbum, eo retius sanat, oratio" ${ }^{\prime 8}$. Kolejnym przełomowym osiagnięciem było wydane w 1718 roku dzieło autorstwa Friedricha Hoffmana, profesora medycyny i filozofii przyrody na Uniwersytecie w Halle, zatytułowane „De morbis recto distinguenda”, w którym zawarł opis etiologii i objawów chorób odbytu użyteczny dla praktyki lekarskiej ${ }^{9}$. Przenikanie nowej jednostki chorobowej do medycyny odbywało się jednak powoli, czego dowodzi zamieszczenie hasła "hemoroidy” w słowniku medycyny i chirurgii wydanym drukiem w 1833 roku w Paryżu ${ }^{10}$.

Józef Frank udostępnił swemu doktorantowi około 30 pozycji literaturowych autorstwa lekarzy niemieckich, wśród których znajdował się spolonizowany chirurg wojskowy Leopold Lafontaine (1756-1812). Na łamach założonego przez siebie „Dziennika Zdrowia dla Wszystkich Stanów” Lafontaine opisał terapię guzków krwawniczych. Znany był Joseph von Quarin (1733-1814), Wiedeńczyk, który ukończył studia lekarskie w wieku zaledwie 15 lat, a czasem został wykładowca anatomii i farmakologii na Uniwersytecie Wiedeńskim. Quarin był on uczniem Antona Störcka i podobnie jak jego mistrz popularyzował stosowanie silnie działających leków roślinnych, w tym cykuty. Józef Frank musiał znać go osobiście i czytać jego prace. Poza Lafontaine i Quarinem oraz paroma innymi wyjątkami nazwiska przywoływane przez M. Gałęzowskiego nic dzisiaj nie mówią, choć kojarzą się ze znanymi lekarzami. Tak jest w przypadku wspomnianego już J. C. de Haëna, który publikował w 1675 roku, kiedy słynnego Antona de Haëna (1704-1776) jeszcze nie było na świecie. Tak było również w przypadku J. C. Stahla, noszącego inne imiona niż słynny lekarz i chemik, twórca błędnej teorii spalania ${ }^{11}$. Warto dostrzec wśród przywoływanych autorów G. W. Wedela, ponieważ zajmował się semiotyką medyczną i poświęcił jej wydane w 1700 roku w Jenie dzieło „Exercitationes semiotico-pathologicae” ${ }^{12}$.

Z rozprawy M. Gałęzowskiego wynika, że opierał się nie tylko na literaturze, ale także na wykładach - być może klinicznych - Józefa Franka, co zwiększa atrakcyjność czytelniczą omawianej dysertacji ${ }^{13}$. Józef Frank uczył wnikliwej obserwacji. Na jej znaczenie wskazał mu ojciec, Józef Piotr Frank, w swoim czasie związany z tzw. starsza szkolą wiedeńską. Dla Macieja Gałęzowskiego najważniejsze było, że lekarz może tak leczyć, aby wyeliminować przyczyny choroby, a więc zaczać od zmiany trybu życia (należało zwiększyć aktywność fizyczną i ograniczyć przesiadywanie) oraz wprowadzić do diety więcej jarzyn, owoców i pokarmów kwaśnych. Gdyby to nie pomogło, lekarz mógł zalecić choremu spożywanie soków owocowych, a także wytwarzanych w aptekach wyciągów roślinnych, związków antymonu, sody, octanu potasu i innych preparatów, w tym specyfiku znanego tylko pod nazwą handlową „Akenside”. Jeżeli

\footnotetext{
Tamże, s. 5-6.

J. Forbes, dz. cyt., s. 98-99.

Dictionnaire de Médicine et de Chirurgie, Paris 1833, s. 169.

M. Gałęzowski, Dissertatio inauguralis..., s. 5-6.

J. Forbes, dz. cyt., s. 97.

13 M. Gałęzowski, Dissertatio inauguralis..., s. 11.
} 
oczekiwana poprawa nadal nie następowała, przychodziła kolej na przemywanie okolic odbytu zimną wodą oraz nakładanie kataplazmów i maści. Jeżeli i te środki nie pomogły, lekarz ustępował pola chirurgowi, zalecając upust krwi. Nie u wszystkich chorych można go było jednak wykonać. Stwardnienie naczyń, czyli miażdżyca, wykluczało taki zabieg. W świetle ówczesnego stanu wiedzy żyły, tętnice i „zepsuta” krew oraz jej zastoje odgrywały pierwszorzędną rolę w powstawaniu guzków krwawniczych. Dziedziczny brak zastawek żylnych jako czynnik sprzyjający tworzeniu się hemoroidów opisał jako pierwszy Giovanni Battista Morgagni (1682-1781).

Rozprawa Macieja Gałęzowskiego ukazuje zatem wiele aspektów medycyny początku XIX wieku: ograniczanie zakresu praktyki chirurgicznej przez lekarzy, fundamentalne znaczenie semiotyki, kształtowanie się wiedzy o miażdżycy i chorobach dziedzicznych. 